\title{
Foreign Exchange Market: Institutional Structure, Regulation, and Policy Implications
}

\author{
Fei Su${ }^{1, *}$, Jun Zhao ${ }^{2}$ \\ ${ }^{1}$ Finance Discipline Group, GTA Finance and Education Group, Shenzhen, China \\ ${ }^{2}$ School of English Studies, Tianjin Foreign Studies University, Tianjin, China \\ *Corresponding author
}

\begin{abstract}
Electronic trading has transformed foreign exchange markets over the past decade, and the pace of innovation accelerates. This formerly two-tier market (namely, the interdealer and customer market) is now evolving into a multi-tier market and transaction costs are only a fraction of their former level. Entirely new agents have joined the fray, including retail and high-frequency traders, while foreign exchange trading volumes have almost tripled to 5.3 trillion dollars daily according to Bank for International Settlements 2013. Market concentration among dealers has risen reflecting the heavy investments in technology. This paper outlines the players in this market and the structure of their interactions. It also presents new evidence on how that structure has changed over the past two decades. Throughout, it highlights issues relevant to market regulation and exchange rate modelling.
\end{abstract}

\section{Keywords: foreign exchange market, institutional structure, regulation, policy implication}

Cite This Article: Fei Su, and Jun Zhao, "Foreign Exchange Market: Institutional Structure, Regulation, and Policy Implications." Journal of Finance and Economics, vol. 5, no. 5 (2017): 195-203. doi: 10.12691/jfe-5-5-1.

\section{Introduction}

It would be hard to overemphasize how important the foreign exchange market is. The average daily trade volume of the foreign exchange market reached to 5.3 trillion dollars in April 2013, which is more than the monthly volume of New York Stock Exchange (NYSE) in 2013 [1]. FX market plays a central role in the financial markets as it provides a way for funding foreign liabilities, for hedging FX risks, for facilitating global portfolio rebalancing, and for implementing monetary policy. Over the last two decades, the importance of the FX market has drawn great interests of policy makers, academics, and the media [2].

When referring to foreign exchange market, it is important to bear in mind the existence of various submarkets and their heterogeneous roles in the FX market. For example, the markets for the emerging market currencies are organized in a different way compared to the markets for the developed market currencies. Also, the FX derivatives markets behave quite differently from the spot market. This thesis mainly focuses on the spot market, which is the second-largest submarket, closely following the FX swap market in 2013 (BIS, 2013a, Table 1), and where most of the price discovery takes place [3]. The FX spot market is a decentralized multiple-dealer market. Traditionally, trades are triggered in a two-layered market, namely, the customer market and interdealer market. The customer market is driven by quotes and the liquidity is provided by the market makers. The customer trades have been conducted through the phone, electronic platforms (i.e. sing-bank, multi-bank, and independent trading platforms), and most recently, electronic brokerage systems and internet-based retail (margin) trading platforms. In the interdealer market, dealers quote prices and trade with each other. Historically, the interdealer market has been characterized by direct dealing (bilateral negotiation) or voice brokers. Nowadays the interdealer trading is largely carried out through electronic brokerages (for example, two of the primary electronic brokerage systems - EBS and Thomason Reuters FX Matching) and Electronic Communication Networks (ECNs). The interdealer market is at the center of the FX market in the sense that the best posted interdealer prices (better known as the "quotes") are used as benchmarks for the customer market and the dealers provide liquidity to other dealers and to their customers. Another market sharing similar characteristics is the US Treasury Bond market.

Unlike the equity or other securities markets, a unified empirical model for the foreign exchange rate is absent. Since the seminal work of Meese and Rogoff argued that the existing model of exchange rate based on macroeconomic fundamentals could not reliably outperform the "naïve" alternative of the random walk forecast for yearly changes in major currency exchange rates, the predictability of the foreign exchange rate movements has been examined extensively [4]. However, no one has yet been able to uncover macroeconomic fundamentals that could explain a modest fraction of the changes of the exchange rate in the real world [5]. Frankel and Rose describe the traditional empirical research on exchange rate as "... the case for macroeconomic determinants of exchange rates is in a sorry state" [6]. Since the mid-1990s, with the availability of proprietary data from the large dealing banks, research on foreign exchange microstructure, or so-called "the new micro exchange rates economics" [5], has accelerated. The researchers on FX market microstructure make an attempt 
to understand the mechanisms generating those deviations from macro fundamentals at short time horizons, which is of great importance for practitioners and regulators (e.g., $[7,8,9])$. For example, the empirical evidence proves that up to two thirds of the level changes and volatilities of exchange rate movements are associated with order flows $[10,11]$.

It is worth noting that the FX market is essentially unregulated like the "wild west", and some well-known regulations in other financial markets are missing in this market [12,13]. For example, there are no government-backed authorities to set rules for FX trading practices; local banking regulators are limitedly responsible for the registration of the dealers/brokers and supervision of clearing and settlements; the self-regulating bodies (i.e. ACI Financial Markets Association (ACI FMA) and regional foreign exchange committees) publish and maintain practical guidance, however, they have neither statutory underpinnings, nor enforcement powers [13]. The breakdown of fixed exchange rate system in 1973 has opened a new era for exchange rates and interest rates volatility [14]. Meanwhile, the FX market in most finance centres has been deregulated as a result of the intensive lobbying activities since the FX is a worldwide attractive industry and the operations would move elsewhere if regulated, which is an undesired result for the policy makers. With lax structure supplying the opportunity and big bonuses creating the motive, "the FX market is designed to encourage crime" [15]. Recently, the ongoing global probes into suspected rigging of Libor (London interbank offered rate), presumably "one of the biggest financial scandal ever" [16], have raised concerns about the vulnerabilities in the international currency markets.

After the financial turmoil of 2008, significant regulatory reforms aiming at stabilizing the financial system and improving financial surveillance in the global financial markets have been proposed and partially implemented [17,18]. However, there have been very few concrete regulatory reforms in the FX market. This has raised the question, on the one hand, of how to evaluate the recent developments in the FX market structure. On the other hand, there is also the question of how to explore the connections between market structure and its regulations, particularly for Emerging Market (EM) currencies. This chapter aims at filling the blank of the previous studies. Firstly, I examine the recent development of the FX market. Secondly, I investigate the evolving structure of the foreign exchange market and its regulations. Last but not least, I provide policy implications regarding the factors that might facilitate improving the transparency of the FX market. Overall, this chapters provides a detailed overview of the FX market structure and lays a foundation for the empirical analysis of the price discover in the FX market in this thesis.

The rest of the chapter is organized as follows: Section 2.2 presents stylized facts on the global FX market. Section 2.3 describes the two-tier market structure and its evolution. A brief comparison of regulations on the U.S. financial markets is given in Section 2.4. The final section concludes with the summary and policy implications.

\section{An Overview of FX Market}

Foreign exchange trading is conducted on a worldwide basis. FX transactions occur continuously from Asia-Pacific to Europe to America. Throughout the day, the trading peaks during the "London-New York overlapping period" (13:00 GMT to 15:00 GMT) when London's afternoon trading overlaps with New York's early morning trading, and tapers off over the "overnight period" (22:00 GMT to 23:00 GMT) when the New York market closes and the Sydney market traders are still on their way to work.

\subsection{Geographical Distribution of Turnover}

Trading in the FX market hits a record high of $\$ 5.3$ trillion daily in April 2013 - a significant rise from $\$ 4.0$ trillion in April 2010 and \$3.3 trillion in April 2007 respectively [1]. Foreign exchange market transactions remain heavily concentrated in a few global financial hubs, namely, the United Kingdom, which accounts for $41 \%$, the United States 19\%, Singapore 5.7\%, Japan 5.6\%, and Hong Kong SAR 4.1\%, of which the United Kingdom plays a dominant role in FX trading [1] ${ }^{1}$. The top five financial centers accounted for roughly three quarters of global foreign exchange trading volume in March 2013 (Figure 1). Besides, due to the increasing internationalization of the emerging market (EM) currencies, the United Kingdom also has established its leading role in the offshore markets for EM currencies. Its market share of volume involving EM currencies has largely expanded from $13 \%$ in 2007 to $30 \%$ in 2013 , followed distantly by the United States with a $16.4 \%$ share in 2013 [19] Geographically, West Europe, North America, and Asia-Pacific are the regions where the foreign exchange trading concentrated in. In contrast, Latin America, Africa, and the Middle East each account for less than $1 \%$ of global FX volume. While the traditional finance centers maintain their status as global financial hubs, the emerging markets (e.g. Shanghai, Taipei, and Kuala Lumpur) are gaining market shares rapidly with the efforts of the local government to promote their cities as global financial centers.

From 2010, foreign exchange trading has been conducted more locally (Table 4). The volume of local transactions has reached a historical high of $42.26 \%$ of total FX trading volume. Correspondingly, the share of cross-border FX transactions fell to $57.74 \%$ in 2013 from $65 \%$ in 2010, reversing the trend since the 2001 BIS survey (Figure 2). The decreasing importance of cross-border transactions is also evident in other over-the-counter (OTC) markets, such as interest rate derivatives [1]. The shrinking cross-border trading is not indicating that trading activities are becoming more local. Instead, with the FX trading increasingly concentrated within a few large financial centers as documented above, a larger proportion of FX trading has been conducted between counterparties located in the same place, but their headquarters could be elsewhere [1].

\footnotetext{
${ }^{1}$ United Kingdom's dominant role in the FX market grew out of its traditional domination for economy in the nineteenth century as well as its unique geographic place - London's afternoon trading overlaps with New York morning trading.
} 


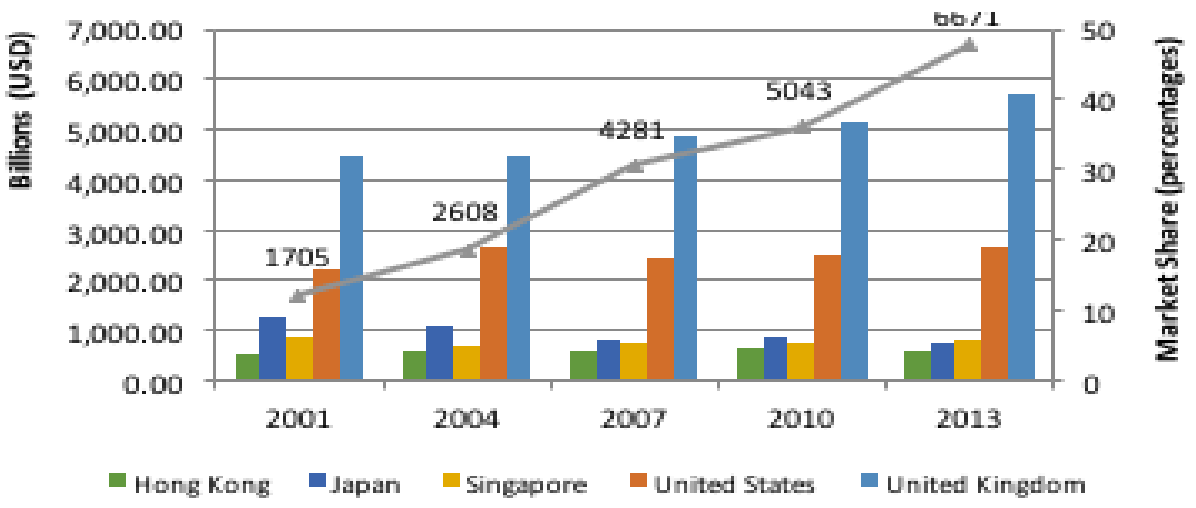

Sources: The BIS Triennial Central Bank Survey, BIS calcutions.

Figure 1. Geographical destribution of global FX market turnover

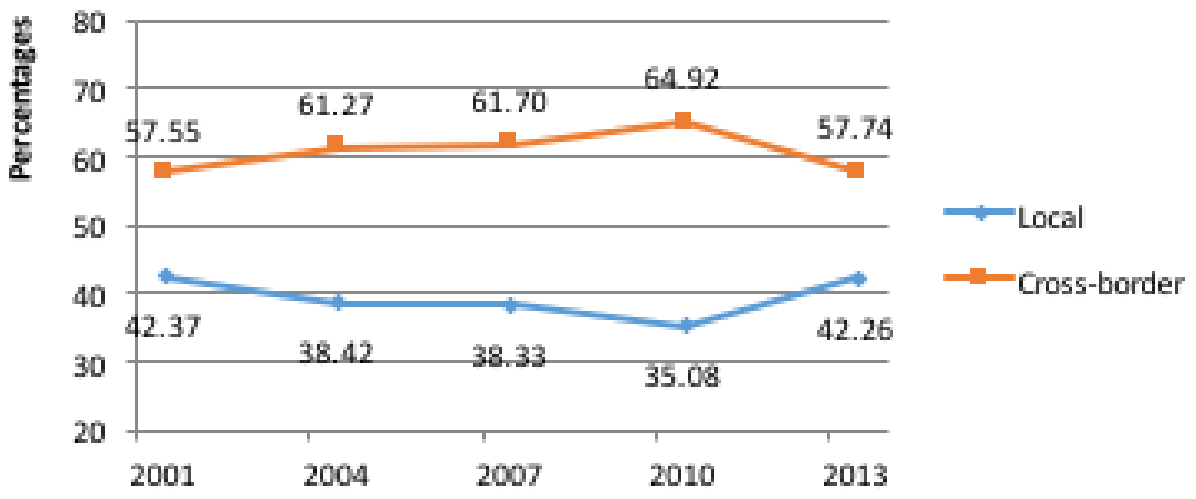

Sources: Triennial Central Bank Survey, BIS calculations

Figure 2. Local and cross-border transactions in global FX market activity

\subsection{Turnover by Currency Pairs}

Among the major currencies, the dominant role of the U.S. dollar in the FX market remains, for example, to trade almost any currency which is not U.S. dollars demands one to exchange the first currency for dollar then convert it from dollars into another currency. The U.S. dollar constituted one side or the other in $87 \%$ of all FX transactions initiated in April 2013, about 2 percent higher than that in 2010 (Table 2). The trading through the "vehicle currency" concentrates foreign exchange liquidity within a relatively narrower range, thus essentially reduces overall transaction costs [13]. Compared with other major currencies, the Japanese yen has surged over the past three years and expanded its market share by 4 percentages to $23 \%$ in 2013. Besides, the market share of the Australian dollar has doubled from $4.3 \%$ in 2001 to $8.6 \%$ in 2013 . In contrast, even though the euro remains the second most-traded currency, the market share of euro has dropped to the lowest level (33.4\% in April 2013) since the outburst of the euro area's sovereign debt crisis in early 2010 (Table 1).

Trading in the emerging market currencies has grown rapidly, which averaged \$1.1 trillion daily in April 2013 [19]. More than a decade ago, the authorities in more than half of the emerging market economies strictly prohibited operating in offshore currency markets [20]. Nowadays, the offshore trading has accounted for roughly $68 \%$ of total volume of emerging market currencies, far exceeding the volume of onshore markets [19]. As an important gauge of currency internationalization, the high proportion of off shore trading indicates that the emerging market currencies are increasingly international, among which the Chinese yuan (Renminbi) is playing a dominant role in emerging Asia [2]. With a 2.2\% market share of global FX volume, the renminbi has been the 9th most actively traded currency in April 2013, mainly driven by the increasing efforts of the Chinese government to internationalize its currency and a significant expansion of Offshore Chinese renminbi $(\mathrm{CNH})$ trading via Hong Kong. However, a breakdown of the offshore activities showed that the renminbi mainly served as a regional instead of an international currency [19].

Table 1. Geographical Distribution of Global FX Market Turnover (Daily averages in April, in percentages)

\begin{tabular}{lccccc}
\hline Currency & $\mathbf{2 0 0 1}$ & $\mathbf{2 0 0 4}$ & $\mathbf{2 0 0 7}$ & $\mathbf{2 0 1 0}$ & $\mathbf{2 0 1 3}$ \\
\hline Advanced Economy Currency & & & & \\
\hline US dollar & 89.9 & 88.0 & 85.6 & 84.9 & 87.0 \\
Euro & 37.9 & 37.4 & 37.0 & 39.1 & 33.4 \\
Japanese yen & 23.5 & 20.8 & 17.2 & 19.0 & 23.0 \\
Pound sterling & 13.0 & 16.5 & 14.9 & 12.9 & 11.8 \\
Australia dollar & 4.3 & 6.0 & 6.6 & 7.6 & 8.6 \\
\hline Emerging Economy Currency & & & & \\
\hline Mexico peso & 0.8 & 1.1 & 1.3 & 1.3 & 2.5 \\
Chinese yuan & 0.0 & 0.1 & 0.5 & 0.9 & 2.2 \\
Russian ruble & 0.3 & 0.6 & 0.7 & 0.9 & 1.6 \\
Turkish lira & 0.0 & 0.1 & 0.2 & 0.7 & 1.3 \\
South African rand & 0.9 & 0.7 & 0.9 & 0.7 & 1.1 \\
\hline
\end{tabular}

Sources: Triennial Central Bank Survey, 2013. 


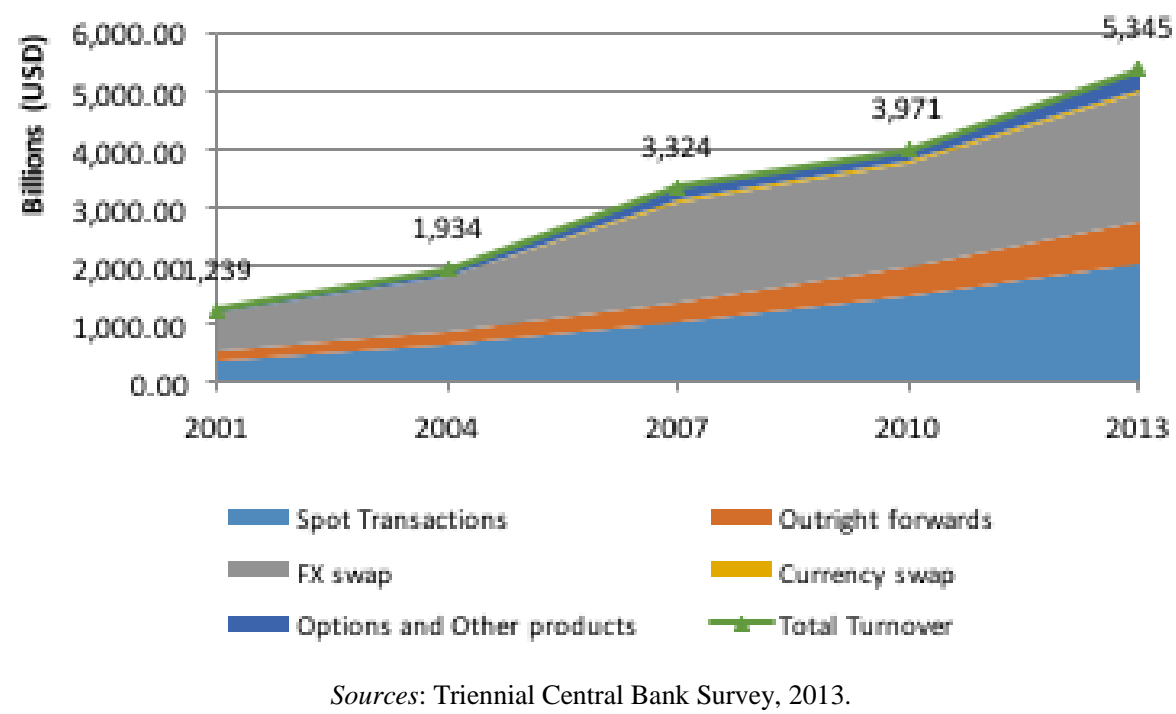

Figure 3. Global FX market turnovers by instruments (Daily averages in April, in billions of US dollars)

\subsection{Turnover by FX Instruments}

FX swaps were the most traded FX instruments, expanding to $\$ 2.2$ trillion per day in April 2013. Like repurchases (repos) in the fixed income markets, FX swaps were utilized initially for bank's night position management [2]. After Lehman Brothers' bankruptcy in late 2008, the central banks expanded swap activities to stabilize the world banking system, a primary reason for the large expansion in the volume of swap [21]. Spot transactions ranked a close second in the FX instruments, rising to \$2.0 trillion per day in April 2013 (Figure 3). Besides, spot transactions deserve particular attention because extensive empirical research on FX microstructure focuses exclusively on spot market, where most of the trading and the price discovery occurs [7].

As been true for decades, the vast majority of FX trading (including spot transactions) is transacted over-the-counter (OTC). The OTC trading volume greatly exceeds that of exchange-traded products (ETP), e.g. the daily average of standardized products traded on exchanges was $\$ 160$ billion in April 2013, less than 3\% of the OTC volume (Table 1). A potential consequence is that the common market practice of reading speculative positions in currencies from open interest on exchanges remains risky and subject to inaccuracy [1].

\subsection{Turnover by Market Participants}

Among the two-tier markets, the interdealer trading has kept pace with the growth in the global FX activity over the past three years, standing at $39 \%$ of total global volume in 2013. The share of FX interdealer trading is comparable to that of the London Stock Exchange (LSE), for which the estimated share is between 25 to 35 percent in 2005 [22].

In the customer market, the market share of dealers' transactions with financial customers has almost doubled in the last decade, from $28 \%$ of total FX volume in April 2001 to $52 \%$ in April 2013 (Figure 4). As these non-dealing financial institutions are heterogeneous in their levels of risk tolerance, liquidity requirements, and trading motivations, a detailed breakdown of the FX financial customers sheds further light on their market shares and trading patterns than ever before [1]. As shown in Figure 2- Figure 5, an important part of dealers' trades is with non-reporting banks. These small and regional banks are responsible for almost one fourth of global FX volume in April 2013, even though they are not engaged in market making activities. ${ }^{2}$ Another two quantitatively significant groups of FX financial customers are institutional investors, and funds and proprietary trading firms. Both groups have a market share of about $11 \%$ in global FX activity (Figure 5).

Dealers' transactions with non-financial customers (e.g., corporates, governments, and individuals), by contrast, decreased from $\$ 532$ billion in 2010 to $\$ 465$ billion in 2013. As a result, the share of trading with non-financial customers has been cut in half since 2007, accounting for $9 \%$ of global FX volume in 2013. The FX market is still mainly dominated by the institutional investors, and only a small fraction of trades recorded was with retail customers in 2013 (i.e., about 3.5\%). The decreased volume in the retail market is probably due to more stringent investor protections after the financial crisis of 2008. The new regulatory controls on the retail market, which require enhanced transparency and oversight, make retail FX less attractive and lead currency managers to shift away from the market [23].

Dealers' trading with official sector (e.g., central banks and sovereign wealth funds) is responsible for less than $1 \%$ of global FX volume in April 2013. Rime and Schrimpf emphasize that these institutions, albeit a small amount, can have a strong impact on currency prices with their intervention operations [2]. For example, the central banks usually possess superior information over other market participants, partially form their ability to require confidential information and their influential power to affect price discovery of other banks [20]. The strong influence of the central banks may also lie in the fact that monetary authorities are better at detecting and interpreting the financial stress [24]. Thus, central bank may have a substantial impact on the currency price as their.

\footnotetext{
${ }^{2}$ As the non-dealing banks are hard to compete with the dealing banks to offer competitive prices, these small and regional banks work as customers of the large dealing banks and exploit their competitive edge towards local clients [2].
} 


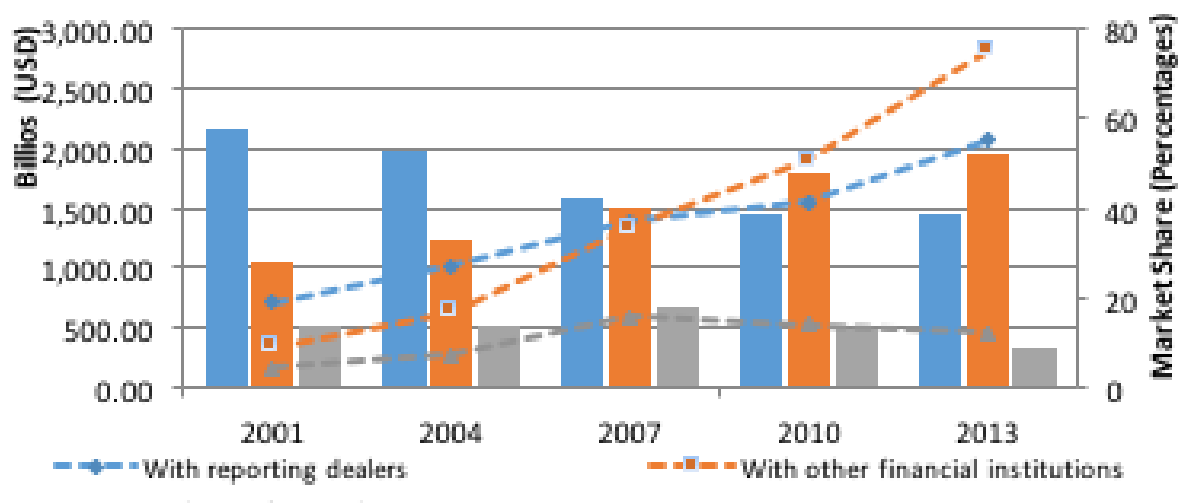

Sources: Triennial Central Bank Survey, 2013.

Figure 4. Global FX market turnovers by counterparty (Daily averages in April, in billions of U.S. dollars)

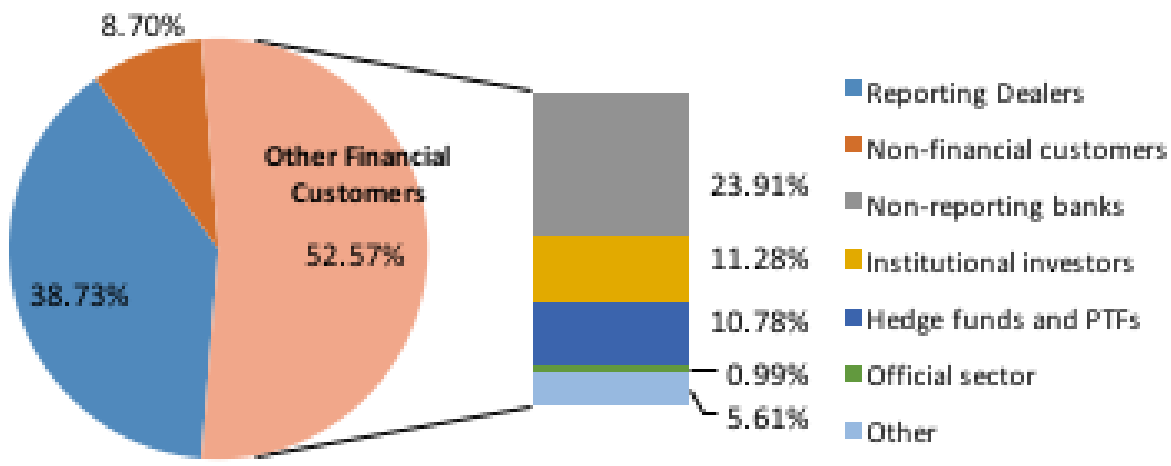

Sources: Triennial Central Bank Survey, 2013.

Figure 5. Global FX market turnovers by institutions (Daily averages in April, in billions of US dollars)

\section{Market Structure of the FX Market}

The FX market has arisen to facilitate international trade and investment through the trading of currencies. With the motivation for currency exchange expanding through centuries to include arbitrage, hedging, and speculation, the scope of important players has expanded accordingly. Beyond commercial firms which are mainly involved in imports and exports, the major market participants now include brokers, dealing and non-dealing banks, currency managers, central banks, and recently, high-frequency traders and individuals.

The conventional foreign exchange market is a twolayered market. In the first layer, dealers trade internally with each other. The second layer is the customer market where the dealers can trade with customers externally. The interdealer market lays the foundation for the FX trading in the sense that the best interdealer price available forms the basis of the customer price (also known as the "quotes") and the dealers provide liquidity to each other as well as to their customers [13]. Besides, the dealers need to hedge inventory risk in the interdealer market, i.e. to lay off inventory on other dealers quickly [13].

\subsection{Interdealer Market}

In the FX market, dealers (or "market makers") have appeared naturally to fulfil the searching function among counterparties in the transactions. Before the mid-1990s, roughly half of the interdealer trading was conducted via direct dealing, for example, a dealer needing liquidity could ask for a quote from another dealer, while the other half was conducted in a limit order market where orders were placed and matched through voice brokers [26]. A dealer who wants to supply liquidity will place a limit order, which specifies the price at which he/she is willing to buy (the "bid") or sell (the "ask") for a certain amount of currencies. The best posted bid or ask prices are known as the "quotes". The set of unexecuted limit orders, which represents the supply of liquidity, is maintained by the brokers and called the "limit order book". Trade occurs when another dealer who demands liquidity enters a market order. ${ }^{3}$ Compared to direct trading, the limit order market is more transparent in the sense that the orders are partially revealed and publicized. Also, the limit order market is anonymous as it is impossible to identify the counterparty until the deal is struck.

Dealers generally prefer to keep their inventory as close to zero as possible, intraday and overnight, i.e. the dealer usually passes any inventory imbalance quickly to others via aggressive order strategies [27]. The estimated half-life of an inventory position ranges from one minute for mostly active dealers at large banks to below half an hour for less active dealers at small banks $[13,28]$. In this respect, it differs markedly from other OTC markets. On

\footnotetext{
${ }^{3}$ The liquidity-demanding dealer can trade immediately at the market price as well as place a price-contingent order (i.e., stop-loss or takeprofit order) to trade at the market price once the price has risen (fallen) to a pre-specified level. For a full discussion of the informativeness of different order types, please see Osler et al. and the references therein [9].
} 
the New York Stock Exchange (NYSE), for example, the half-life of inventory averages over a week [29]. Even on a more active interdealer market such as the London Stock Exchange (LSE), the inventory half-life averages 2.5 trading days [30]. Traditionally, after trading with customers the dealer will keep passing the position onto another dealer until the inventory imbalance is eliminated through customer trades, a process known as "hot potato trading" [7]. On some other OTC markets (e.g., the US bond market), in contrast, the dealers typically "warehouse" the risk (i.e. holding the inventory for their own account) and "shade" the quoted prices to attract the customer trades coming in directions they prefer [31].

Since the emergence of the electronic brokerages, the interdealer trading in the FX market has been changed hugely. In 1992, the first electronic limit-order market was introduced by Reuters, now it is called "Thomson Reuters Matching". Worried about Reuters' threatened monopoly in interbank spot trading, a consortium of major marketmaking banks created another platform - the Electronic Broking Service (EBS) a year later, which was then acquired by ICAP - the world's largest interdealer brokerage firm, in 2006. By the end of the 1990s, the liquid currencies have been dominated by the electronic brokers, while voice brokers remained important in illiquid currencies as well as various "complex" FX instruments which were not suitable for trading over electronic brokerage. Voice-executed transactions accounted for about $42 \%$ of global FX volume in April 2013, of which $45 \%$ of FX swaps and $34 \%$ of spot transactions were executed via voice brokers [1]. Due to network externalities, liquidity is naturally concentrated on one platform for each currency. For example, the interbank trading for the EUR, the JPY, and the CHF has long been dominated by EBS, while Reuters dominates the trading of "commonwealth currencies" (i.e. the GBP, the AUD, the CAD, and the NZD) and the emerging market (EM) currencies [13].

As the electronic brokers rapidly gained popularity, their best posted quotes became the benchmark for market prices, which enhanced transparency and narrowed bidask spread. ${ }^{4}$ The electronic brokers have enhanced pretrade transparency by providing streamlined real-time quotes. Post-trade transparency has also been enhanced in the sense that mandatory reporting of trade deals has been proposed and implemented in some cases. ${ }^{5}$ The introduction of interdealer electronic markets also benefits the small banks, since the anonymous trading environment does not permit price discrimination, thereby reduces transaction costs [13]. However, the interdealer FX market is still perceived as much less transparent compared to most other limit-order markets. As for pre-trade information, currency prices are limited to the best bid and offer quotes. The only post-trade information is a listing of transaction prices. Besides, unlike equities markets where trading volume must be disclosed on a regular basis, the only information source on aggregated trading volume

\footnotetext{
${ }^{4}$ For example, for the most liquid currency pairs (i.e., EUR/USD), the bid-ask spread during active trading hours are often narrower than one basis-point (BP).

${ }^{5}$ For example, for the most liquid currency pairs (i.e., EUR/USD), the bid-ask spread during active trading hours are often narrower than one basis-point (BP).
}

is the BIS Triennial Central Bank Survey, which is updated every three years. ${ }^{6}$

\subsection{Customer Market}

The customer market is driven by quote and market makers provide the instantaneous liquidity [32]. To initiate an FX trade, a customer can call a dealer and ask for the quotes for a certain amount of currencies. Correspondingly, the dealer would quote the prices at which he/she is going to buy (the "bid") and to sell (the "ask"). As in most other such over-the-counter (OTC) markets, compensation will be provided to the dealer for the risks associated with liquidity provision (i.e. inventory risk, counterparty risk, among others) by a favourable gap between the buying and selling quotation, better known as the "bid-ask spread". Dealers on the FX market have no formal obligation to make market, unlike specialists on the NYSE or designated market makers (DMM) on the NASDAQ who are obligated to maintain a fair, orderly market [33]. However, if dealers can't provide the liquidity as required, it will cause trouble such as ruined reputations; in this case, dealers have to be reliable. For example, the FX market continued uninterruptedly and functioned successfully even in the events of September 11, 2001 [34]. However, the traditional customer market is fairly decentralized and opaque. The information on quotes and transactions is private to the dealers and the customers involved.

Customers began to use electronic trading around 1996 when the custodian bank State Street launched the first proprietary single-bank trading platform FX Connect, which became a multi-bank system in 2000 [13]. The first multi-bank trading system Currenex was launched in 1999. In these multi-bank ECNs, instead of calling to find the best quotes, customers could send a "request-for-quote" (RFQ) to many FX dealers electronically and then choose to trade with the dealer offering the best quotes [13]. On some other new entrants, like Hotspot FX and Lava, electronic limit-order markets have been introduced which allow customers to trade anonymously and continuously. Responding to the competitions from the new entrants, the major banks continued to invest heavily in IT infrastructure to develop and implement the proprietary single-bank trading system for their own customers, as well as banded together to set up multi-bank trading platforms, such as FXall. An overview of the top multi-bank trading systems in the FX customer market is presented in Table 2.

The rise of electronic trading has also quickly led to narrower spreads for customers. Before the late 1990s, the average bid-ask spread paid by non-financial corporates in customer market was roughly 20 times that in interdealer market [28,35]. Till now, the difference in spreads between the two FX segments has almost disappeared or even reversed [13]. ${ }^{7}$ Besides, "straight-through processing" (STP) is enabled via electronic trading, which means

\footnotetext{
${ }^{6}$ Now, semi-annual regional surveys are regularly conducted by local foreign exchange committees in major financial centers, such as Australia, Canada, London, New York, Singapore, and Tokyo.

${ }^{7}$ On some of the new entrant platforms, customers enjoy a narrower spread than in the traditional interdealer market, probably driven by intensive competitions to attract customer order flows between dealers [13].
} 
anything related to trade can be done with electronic devices. Because the straight-through processing enables the trading process to be operated electronically, the human errors are minimized, and operational risk and operating costs are being dramatically lowered.

Table 2. An Overview of Multibank Trading Systems for Customer Market

\begin{tabular}{lcc}
\hline Request-for-quote (RFQ) service & & \\
\hline Platform & Year & Mkt Share \\
\hline FX Connect & 1996 & $14.71 \%$ \\
FXall & 2001 & $26.08 \%$ \\
360 Treasury Systems & 2002 & $13.23 \%$ \\
Reuters Trading for FX & 2005 & n.a. \\
\hline Pre-trade anonymous limit order book & & \\
\hline Platform & Year & Mkt Share \\
\hline Reuters Dealing 3000 & 1992 & $11.46 \%$ \\
EBS Market & 1993 & $12.31 \%$. \\
Currenex & 1999 & $11.91 \%$ \\
Hotspot FX & 2000 & $5.43 \%$ \\
\hline
\end{tabular}

Sources: Euromoney FX Survey 2013.

\section{Regulations of the FX Market}

The vast majority of FX trading is essentially unregulated, in striking contrast to the extensive regulations on securities markets. Some well-known regulations on illegal practices (e.g., insider trading, front running, flash trading, etc.) are essentially missing in the wholesale FX market. Overall there is no governmental authority to define acceptable trading practices. Local banking regulators are limited to supervising trading processing such as clearing and settlement. The self-regulating bodies publish and maintain the codes of conduct to promote best market practices; however, the members are not bound by any of the recommendations and opinions in a legal sense [14].

Spot transactions, which were on the order of $\$ 2$ trillion per day in April 2013, are not even considered as financial instruments in the context of market regulation. For example, as implemented in practice, many FX deals including spot transactions are outside the scope of direct regulation pursuant to the Financial Services and Markets Act 2000 (FSMA) - the principal legislation governing the foreign exchange market in U.K. (Bank of England, 2009). From an EU regulation perspective, FX spot transactions as well as forward transactions are not considered to be financial instruments under MiFID - the Markets in Financial Instruments Directive, a comprehensive regulatory framework in the European Union (European Commission, 2009). Spot foreign exchange transactions are also exempted from the Dodd-Frank Act, which seeks to regulate OTC derivative markets in US (Commodity Futures Trading Commissions, 2009). The views of the regulators may partly explain the scarcity of regulations concerning FX trading. For example, it is claimed by the Bank of England that the FX market performed resiliently after the bankruptcy of Lehman Brothers (Bank of England, 2009). Also, in the US Treasury Secretary's statement on December 2, 2009, it claimed that "[the FX] markets actually work quite well. ..., and our judgment is because of the protection that already exists in these foreign exchange markets" (Timothy Geithner, Dec 2, 2009).

Yet the largely unregulated global FX market thrived and expanded for decades in the major financial centers, the collapse of the fixed exchange rate system in 1973 has opened "a new era in exchange and later interest rate volatility", which highlighted the need for a more formal international approach to market conduct and ethics. In 1975, the first practice guideline, known as "the ACI Model Code", was published by ACI - The Financial Markets Association, an international self-regulating body in the wholesale financial market. There followed similar guidelines published by local foreign exchange committees in major financial centers, i.e. New York (1980), London (1990), Singapore (1991), Hong Kong (1992), and Tokyo (1995). Across these financial centers, the foreign exchange committees in Hong Kong, London, New York, Singapore and Tokyo publish and maintain their own codes of conduct. The European Union and Australia, along with a number of other regions or countries, use the ACI Model Code. The self-regulating bodies and their practice guidelines are presented in Table 3.

Table 3. Self-regulating Bodies and Practice Guidelines in FX market

\begin{tabular}{|c|c|c|c|}
\hline Country/ Region & Year & Self-regulating Body & Codes of Conduct \\
\hline Global & 1901 & ACI - The Financial Markets Association & The ACI Model Code (January 2013) \\
\hline European Union & 1995 & ECB's Foreign Exchange Contact Group & The ACI Model Code (January 2013) \\
\hline Hong Kong SAR & 2005 & $\begin{array}{l}\text { The Hong Kong Treasury Markets } \\
\text { Association }\end{array}$ & Code of Conduct and Practice (January 2011) \\
\hline London & 1973 & $\begin{array}{l}\text { The London Foreign Exchange Joint } \\
\text { Standing Committee }\end{array}$ & The Non-Investment Products Code (November 2011) \\
\hline New York & 1978 & The Foreign Exchange Committee & $\begin{array}{l}\text { Codes of Best Market Practice and Shared Global } \\
\text { Principles (May 2013) }\end{array}$ \\
\hline Singapore & 1991 & $\begin{array}{l}\text { The Singapore Foreign Exchange Market } \\
\text { Committee }\end{array}$ & $\begin{array}{l}\text { The Singapore Guide to Conduct and Market Practice for } \\
\text { Treasury Activities (February 2012) }\end{array}$ \\
\hline Tokyo & 1995 & $\begin{array}{l}\text { The Tokyo Foreign Exchange Market } \\
\text { Committee }\end{array}$ & $\begin{array}{l}\text { The Tokyo Foreign Exchange Market Committee Code of } \\
\text { Conduct (September 2008) }\end{array}$ \\
\hline Australia & 1984 & $\begin{array}{l}\text { The Australian Foreign Exchange } \\
\text { Committee }\end{array}$ & The ACI Model Code (January 2013) \\
\hline
\end{tabular}

Note: The dates in parentheses are the release dates of the latest practice guidelines. Sources: The Financial Markets Association - ACI, European

Central Bank, and local foreign exchange committees of Hong Kong SAR, London, New York, Singapore, Tokyo, and Australia. 
Table 4. Brief Comparions of Regulations on Financial Markets in the U.S.

\begin{tabular}{|c|c|c|c|c|}
\hline & Equities & Treasury Bond & OTC Derivatives & Foreign Exchange \\
\hline $\begin{array}{l}\text { Government } \\
\text { Legislation } \\
\text { \& Oversight }\end{array}$ & $\begin{array}{l}\text { SEC } \\
\text { - SEC registration of } \\
\text { prospectuses } \\
\text { - Disclosure requirement } \\
\text { - SEC enforcement of } \\
\text { market manipulation } \\
\text { prohibitions } \\
\text { - Prohibition on false \& } \\
\text { misstatements } \\
\text { - Net capital Rule } \\
\text { - Corporate governance }\end{array}$ & $\begin{array}{l}\text { The Treasury } \\
\text { - Rules regarding government } \\
\text { securities transactions } \\
\text { - Minimum capital requirements; } \\
\text { - Large position reporting rules; } \\
\text { SEC } \\
\text { - SEC registration as } \\
\text { Government Securities Dealers } \\
\text { Federal Reserve Bank of New } \\
\text { York } \\
\text { - Maintaining of prime list }\end{array}$ & $\begin{array}{l}\text { CFTC } \\
\text { - Dealer registration with CFTC } \\
\text { - Oversees trading on the futures } \\
\text { exchanges } \\
\text { - Disclosures in the OTC } \\
\text { derivatives market } \\
\text { - Capital requirement } \\
\text { - Margin requirements } \\
\text { - Real-time public reporting and } \\
\text { recordkeeping }\end{array}$ & $\begin{array}{l}\text { The Federal Reserve } \\
\text { - Registration of foreign } \\
\text { exchange dealers }\end{array}$ \\
\hline $\begin{array}{l}\text { Co- } \\
\text { regulation }\end{array}$ & $\begin{array}{l}\text { Approved exchanges } \\
\text { Listing rules } \\
\text { Surveillance of members } \\
\text { and trading } \\
\text { Obligation to report } \\
\text { wrongdoing to the SEC }\end{array}$ & & $\begin{array}{l}\text { Approved exchanges } \\
\text { CME Business Conduct Rules } \\
\text { - List rules } \\
\text { - Trade reporting rules } \\
\text { - Obligation to report } \\
\text { wrongdoing to the SEC and } \\
\text { CFTC }\end{array}$ & \\
\hline $\begin{array}{l}\text { Self- } \\
\text { regulation }\end{array}$ & $\begin{array}{l}\text { Financial Industry } \\
\text { Regulatory Authority } \\
\text { - Corporate governance } \\
\text { - Code of Ethics and } \\
\text { Practice Notes } \\
\text { - Standard management } \\
\text { contracts } \\
\text { - Regular disclosure } \\
\text { requirements }\end{array}$ & $\begin{array}{l}\text { National Association of Securities } \\
\text { Dealers } \\
\text { - Sales practice rules } \\
\text { - Suitability rules }\end{array}$ & $\begin{array}{l}\text { National Futures Association } \\
\text { - Capital requirements }\end{array}$ & $\begin{array}{l}\text { The Foreign Exchange } \\
\text { Committee } \\
\text { - Codes of Conduct }\end{array}$ \\
\hline
\end{tabular}

Note: ${ }^{1}$ For example, say-on-pay rules which aims at the overpay of the executives. For a comprehensive overview of U.S. financial regulatory policy for banking and securities markets, see Murphy (2013).

Over the past few decades, it has been thought that the absence of regulation is not a problem due to the uniqueness of the FX market [13]. Short-sales restriction, for example, though severe in most other markets, can't even be defined in the FX market because any sale of one currency is accompanied by a purchase of the other. Other practices that are illegal on exchanges are discouraged by market best practices in FX market. For example, frontrunning of customer orders is widely considered bad practice even though it is not illegal. ${ }^{8}$ Flash order, a prohibited practice on most equity exchanges (e.g., Nasdaq stopped allowing brokerages to make flash orders since 2009), is discouraged in the FX market. It has been long believed that the FX market is sufficiently liquid that significant manipulation by any single party is all but impossible during active trading hours for the major currencies [13]. However, the alleged manipulation of London interbank offered rate (hereafter referred to as "Libor fixing"), "the biggest crisis FX market has ever faced" [36], showed that the market concentration has provided the monopolies an opportunity to collude with their competitors and manipulate the benchmark interest rates in currency markets.

Table 4 provides a brief comparison of the financial regulations on securities and foreign exchange markets in US. As documented above, there are essentially neither government-backed regulations nor co-regulations by the approved-exchanges in the FX market, a striking contrast

\footnotetext{
${ }^{8} \mathrm{~A}$ front-running dealer who has the information advantage would buy (sell) before the customer buy (sell) order, thus driving up (down) the price before filling the buy (sell) order from the customer [13].
}

to those on other financial markets. There comes the question of how to enforce compliance when the policy is powerless. Furthermore, the FX market, as a key underpinning of the global financial system, become even more dependent on a small handful of major banks whose failure might pose systemic consequences. Even though in the financial crisis around eight years ago, the FX market performed resiliently (Bank of England, 2009). With the diminishing number of liquidity providers in FX markets, would the remaining banks be capable of absorbing risks in a high-volume, complex-structure currency market? Would the increased concentration lead to systemic risk through contagion and amplification under conditions of extreme stress? These are the important questions left for the regulators on currency market in a global context. ${ }^{9}$

\section{Summary and Implications}

In summary, this chapter discusses the evolution of the market structure and regulations on the FX market over the last few decades. The evolving structure of the FX market has provided us with the motivation behind the issues addressed in this thesis, which will be of great interest to regulators, practitioners and academics.

\footnotetext{
9 As a forum bringing together central banks and private sector participants, the Global Foreign Exchange Committee (GFXC) was established in May 2017. Meanwhile, it published the FX Global Code with the aim to promote a robust, fair, liquid, open, and appropriately transparent Foreign Exchange (FX) market. For a detailed introduction to the GFXC, please refer to http://www.globalfxc.org/.
} 
On the one hand, a fundamental paradigm shift from two-tier to multi-layered market is occurring in the FX market as a result of rising electronic trading. At the same time, the prohibitively high cost of technology investment required to compete with the top-tier FX banks has helped the largest players to consolidate their market leader positions, which has been described as "an unhealthy market share concentration" [37]. These shifts may have a permanent effect on the price discovery process. On the other hand, public concerns regarding under-regulation and market manipulation have arisen in the wake of money market scandals. The lessons from the Libor scandal are also relevant for the trading of emerging market currencies in the internationalization process. Coupled with the absence of government regulation and market share concentration, the manipulations in the FX market have a substantial impact on the trading practice and behaviour of market participants. For example, when asked what causes exchange rates to deviate from fundamental values, $68 \%$ of US dealers blame institutional customers and hedge fund manipulations [26].

\section{References}

[1] Bank for International Settlements (2013). "Triennial Central Bank Survey of foreign exchange and derivatives market activity in 2013." Triennial Central Bank Survey.

[2] Rime, D., \& Schrimpf, A. (2013). The anatomy of the global FX market through the lens of the 2013 Triennial Survey. BIS Quarterly Review, December.

[3] Evans, M. D. (2002). FX Trading and Exchange Rate Dynamics. Journal of Finance, 57(6), 2405-2447.

[4] Meese, R. A., \& Rogoff, K. (1983). Empirical exchange rate models of the seventies: Do they fit out of sample?. Journal of international economics, 14(1), 3-24.

[5] Evans, M. D., \& Lyons, R. K. (2002). Informational integration and FX trading. Journal of International Money and Finance, 21(6), 807-831

[6] Frankel, J. A., \& Rose, A. K. (1995). A survey of empirical research on nominal exchange rates (No. C95-051). University of California at Berkeley.

[7] Lyons, R. K. (2001). The microstructure approach to exchange rates. Cambridge, MA: MIT press.

[8] Evans, M. D., \& Lyons, R. K. (2002). Time-varying liquidity in foreign exchange. Journal of Monetary Economics, 49(5), 1025-1051.

[9] Osler, C. L. (2008). Foreign exchange microstructure. Encyclopaedia of Complexity and System Science.

[10] Love, R., \& Payne, R. (2008). Macroeconomic news, order flows, and exchange rates. Journal of Financial and Quantitative Analysis, 43(02), 467-488.

[11] Evans, M. D., \& Lyons, R. K. (2005). Do currency markets absorb news quickly?. Journal of International Money and Finance, 24(2), 197-217.

[12] Felix, Salmon (2013). "Annals of market manipulation, FX edition", Bloomberg News June 12, 2013.

[13] King, M. R., Osler, C., \& Rime, D. Foreign Exchange Market Structure, Players, and Evolution. Handbook of Exchange Rates, $1-44$.

[14] ACI Financial Markets Association (2013). The ACI Model Code. pp. 2-3.
[15] Patrick Jenkins (2013). "The forex market is designed to encourage crime", Financial Times November 6, 2013.

[16] The Economist The rotten heart of finance, accessed August 21, 2013. http://www.economist.com/node/21558281.

[17] Sheng, A. (2009). From Asian to global financial crisis: an Asian regulator's view of unfettered finance in the 1990s and 2000s (Vol. 3). Cambridge University Press.

[18] Kuroda, H., \& Kawai, M. (2012). Strengthening regional financial cooperation in East Asia. Financial governance in East Asia: policy dialogue, surveillance and cooperation, 136-66.

[19] Ehlers, T., \& Packer, F. (2013). FX and derivatives markets in emerging economies and the internationalisation of their currencies. BIS Quarterly Review, December.

[20] Canales-Kirilenko, J. I. (2001). Foreign exchange market organization in selected developing and transition economies: evidence from a survey. IMF Working Paper.

[21] Melvin, M., \& Taylor, M. P. (2009). The crisis in the foreign exchange market. Journal of International Money and Finance, 28(8), 1317-1330

[22] Reiss, P. C., \& Werner, I. M. (2005). Anonymity, adverse selection, and the sorting of interdealer trades. Review of Financial Studies, 18(2), 599-636.

[23] Morgan Stanley Research (2014). "FX Pulse". January 30, 2014.

[24] Grimaldi, M. (2010). Detecting and interpreting financial stress in the euro area. ECB Working Paper No. 1214.

[25] Vitale, P. (2011). The impact of FX intervention on FX markets: a market microstructure analysis. International Journal of Finance \& Economics, 16(1), 41-62.

[26] Cheung, Y. W., \& Chinn, M. D. (2001). Currency traders and exchange rate dynamics: a survey of the US market. Journal of international money and finance, 20(4), 439-471.

[27] Osler, C. L., Mende, A., \& Menkhoff, L. (2011). Price discovery in currency markets. Journal of International Money and Finance, 30(8), 1696-1718.

[28] Bjønnes, G. H., Rime, D., \& Solheim, H. O. A. (2005). Liquidity provision in the overnight foreign exchange market. Journal of International Money and Finance, 24(2), 175-196.

[29] Madhavan, A., \& Smidt, S. (1993). An analysis of changes in specialist inventories and quotations. The Journal of Finance, 48(5), 1595-1628.

[30] Hansch, O., Naik, N. Y., \& Viswanathan, S. (1998). Do inventories matter in dealership markets? Evidence from the London Stock Exchange. The Journal of Finance, 53(5), 1623-1656.

[31] Dunne, P. G., Hau, H., \& Moore, M. (2010). A tale of two platforms: dealer intermediation in the European sovereign bond market.

[32] Grossman, S. J., \& Miller, M. H. (1988). Liquidity and market structure. the Journal of Finance, 43(3), 617-633.

[33] Korczak, P., \& Phylaktis, K. (2010). Related securities and price discovery: Evidence from NYSE-listed Non-US stocks. Journal of Empirical Finance, 17(4), 566-584.

[34] Mende, A. (2006). 09/11 on the USD/EUR foreign exchange market. Applied Financial Economics, 16(3), 213-222.

[35] Goodhart, C., Love, R., Payne, R., \& Rime, D. (2002). Analysis of spreads in the dollar/euro and deutschemark/dollar foreign exchange markets. Economic Policy, 17(35), 535-552.

[36] Arnold, M., \& Dunkley E. "Libor's long and wild ride is coming to an end," Financial Times, July 2017. [Online]. Available: https:///www.ft.com/content/88d0dfee-72e0-11e7-aca6c6bd07df1a3c. [Accessed Aug. 28, 2017].

[37] Lee, O., "FX poll 2009: Staying power in troubled times," Euromoney, May 2009. [Online].

Available:https://www.euromoney.com/article/b1322p6mhqrbsz/f x-poll-2009-staying-power-in-troubled-times.[Accessed Aug. 28, 2017]. 